\title{
MEIS-1 level in unresectable hepatocellular carcinoma can predict the post-treatment outcomes of radiofrequency ablation
}

\author{
Hui Xie ${ }^{1,2}$, Haipeng $\mathbf{Y u}^{1}$, Shengtao Tian'2 ${ }^{2}$ Xueling Yang ${ }^{1}$, Ximing Wang ${ }^{2}$, Huaming \\ Wang $^{2}$ and Zhi Guo ${ }^{1}$ \\ ${ }^{1}$ Department of Interventional Therapy, Tianjin Medical University Cancer Institute \& Hospital, National Clinical Cancer \\ Research Center, Key Laboratory of Cancer Prevention and Therapy, Tianjin 300070, PR China \\ ${ }^{2}$ Department of interventional therapy, 302 Hospital of People's Liberation Army, Beijing 100039, PR China \\ Correspondence to: Zhi Guo, email: gztjzlyy@163.com \\ Huaming Wang, email: wanghm302@163.com \\ Keywords: RFA; MEIS-1; unresectable HCC; prognosis \\ Received: August 29, 2017 Accepted: December 01, 2017 Epub: January 11, 2018 Published: March 16, 2018
}

Copyright: Xie et al. This is an open-access article distributed under the terms of the Creative Commons Attribution License 3.0 (CC BY 3.0), which permits unrestricted use, distribution, and reproduction in any medium, provided the original author and source are credited.

\section{ABSTRACT}

Radiofrequency ablation (RFA) is a local-ablative therapy for unresectable hepatocellular carcinoma (HCC). At present, there is no predictive marker for RFA treatment outcomes. This work aimed to valuate myeloid ecotropic viral integration site 1 (MEIS-1) in predicting post-RFA treatment outcomes of unresectable HCC patients. The time to progression (TTP) and overall survival (OS) of 81 HCC patients who received RFA treatment were measured. The protein level of MEIS-1 in tumor specimens was measured by western blot. The role of MEIS-1 in RFA-treating HCC in vivo growth nude mouse model was examined via PET/CT imaging. Higher level of MEIS-1 in tumor tissue is associated with better RFA treatment outcomes. The median TTP was 9.0 (95\% confidence interval $[\mathrm{CI}]:$ 6.8-11.3) months in patients with high MEIS-1 expression $(n=43)$ versus $6.0(95 \% \mathrm{CI}: 4.6-7.4)$ months in patients with low MEIS-1 expression $(n=38)$. Moreover, in rodent HCC model we found overexpression of MEIS-1 enhanced the anti-tumor effect of RFA treatment. We conclude that high level of MEIS-1 expression predicts better RFA treatment outcome in HCC.

\section{INTRODUCTION}

High proportion of hepatitis viruses infection makes China a heavily afflicted country of hepatocellular carcinomas (HCCs); effective HCC treatment approaches will relieve this urgent medical burden [1-3]. Normally HCC cannot be diagnosed until developed into advancedstage which is not suitable for liver transplantation or surgical resection. There are limited treatment options available for advanced HCC patients, current HCC treatments have poor clinical outcomes and poor prognosis [4-6]. Radiofrequency ablation (RFA), an in situ ablative therapy which selectively destroys HCC tissues, is a promising treatment for advanced-stage $\mathrm{HCC}$ patients with cirrhosis and compromised liver function [7-10]. However, rapid or aggressive recurrence of HCCs after RFA treatment is a major obstacle [11]. It is urgent to study the mechanisms of the recurrence of HCCs after
RFA treatment and identify predictive prognosis marker of HCC patients.

Transcription factor myeloid ecotropic viral integration site 1 (MEIS-1) is a member of the triple amino acid loop extension family, which are thought to play important roles in cell growth and differentiation during vertebrate embryogenesis [12]. MEIS-1 contains four functional domains: a N-terminal MEIS-A domain, a MEIS-B domain, a C-terminal transcription factor activity region, and a homeodomain, which links MEIS-B domain and the C-terminal region [13, 14]. Previously, MEIS-1 was reported as a positive tumor inducer [1519]. However, MEIS-1 can also function as a negative regulator of cancers by inhibiting cell proliferation and inducing cell cycle arrest [20-21]. A previous study reported higher expression of MEIS-1 in healthy prostate tissues than in prostate carcinoma tissues, and concluded that MEIS-1 may serve as a predictive biomarker of 
prostate cancer prognosis [21]. Similar studies reported that MEIS-1 is a suppressor of non-small-cell lung cancer, esophageal squamous cell carcinomas and clear cell renal cell carcinomas [14, 22-25]. A recent paper reported that MEIS-1's expression level can predict treatment outcome in HCC patients [26].

In this study, we examined the predictive value of MEIS-1 expression in determining post-RFA treatment outcomes in HCC patients with advanced-stage disease. MEIS-1 may function as a negative regulator of HCC growth. Overexpression of MEIS-1 enhanced the efficiency of RFA's anti-tumor effect on HCC cell proliferation in vivo. Thus, high level of MEIS-1 expression predicts better RFA treatment outcome in HCC.

\section{RESULTS}

\section{Association of MEIS-1 protein level and RFA treatment outcomes}

The endogenous protein level of MEIS-1 in clinical specimens was detected by western blot. The results of the quantitative analysis of the western blots are shown in Figure 1A. According to the median value of intratumoral MEIS-1's protein expression, the 81 patients were divided into two groups: those with low MEIS-1 expression $(n=$ $38)$ and those with high MEIS-1 expression $(n=43)$, as shown in Figure 1B.

As shown in Figures $1 \mathrm{C}$ and $1 \mathrm{D}$, and Table 1, the median post-RFA TTP is 9.0 (95\% confidence interval [CI]: 6.8-11.3) months in the high MEIS-1 expression group, whereas it is 6.0 (95\% CI: 4.6-7.4) months in the low MEIS-1 expression group (log-rank $P<0.001$, Figure 1C). However, the difference in the median OS of the two groups seem obvious but is not significant (log-rank $P=$ 0.212 , Figure 1D). As shown in Table 1, patients with high MEIS-1 expression had higher CER and DCR $(39.53 \%$ vs. $15.79 \%, P=0.031$ for CER; $67.44 \%$ vs. $42.10 \%, P=$ 0.022 for DCR) compared with those with low MEIS-1 expression (Table 1).

\section{MEIS-1 enhanced RFA-induced inhibition of $\mathrm{HCC}$ cells in vivo growth}

To validate whether MEIS-1 intrinsicly expression affects tumor growth, we next established HCC cell lines with low or high MEIS-1 expression level. We first selected a HCC cell line MHCC97-H which has very low endogenous MEIS-1 expression (Figure 2A), MEIS1 was overexpressed via infection of its adenovirus -vectors in MHCC97-H cells (Figure 2B). We found the overexpression of MEIS-1 increased the expression of E-cadherin, an epithelial marker, and decreased the protein level of N-cadherin and Vimentin, two mesenchymal markers (Figure 2C and 2D). Therefore, MEIS-1 inhibits the epithelial-mesenchymal transition of MHCC97-H cells.
Next, control MHCC97-H cells or MEIS-1 overexpressing MHCC97-H cells were injected into nude mice subcutaneously. We observed that overexpression of MEIS-1 reduced tumor growth, and the RFA treatment resulted in shrinkage of the tumors (Figure 3A-3C). Moreover, RFA induced the EMT process of HCC tumors, MEIS-1 inhibited the EMT induced by RFA (Figure 3D$3 \mathrm{G})$. Thus, overexpression of MEIS-1 enhances the antitumor effect of RFA treatment.

Next, HCC cells were isolated from the subcutaneous tumors (Figure 3) that had been treated with RFA or infected with vectors; transwell assays (in vitro invasion or migration) and intrahepatic growth assay (injected into the liver lobe) were performed. As shown by the results of the soft agar assay, overexpression of MEIS-1 or RFA attenuated in vitro invasion (Figure 4A) and migration (Figure 4B) of HCC cells.

To confirm the results in in vivo tumor growth, the effect of MEIS-1 on RFA was examined by inducing expression model. MHCC97-H cells infected with control virus or TET-on virus which express MEIS-1 were injected into nude mice subcutaneously. When the volumes of subcutaneous tumors reach $1200 \mathrm{~mm}^{3}$, the RFA was performed. Next, mice received solvent control or tetracycline (Tetracycline does not affect HCC tumor growth, shown in Supplementary Figure 1). As expected, tetracycline treatment induced the overexpression of MEIS-1 and reduced tumor growth (Figure 5); and the RFA treatment resulted in tumor size reduction (Figure 5).

Moreover, we validated our hypothesis in in situ HCC cell growth model in which the intraliver tumors were measured by PET/CT. As shown in Figure 6A, RFA treatment decreased the intrahepatic growth of HCC cells. Overexpression of MEIS-1 enhanced the inhibitory effect of RFA on HCC cells' nodule formation in liver (Figure 6A). The liver-to-blood radioactive data, tumor foci in the whole liver, and PET imaging of the whole liver confirmed the PET imaging of whole animals (Figure 6B). Thus, overexpression of MEIS-1 enhanced the anti-tumor effect of RFA treatment in in situ HCC.

\section{DISCUSSION}

It is well known that advanced HCC patients have a poor prognosis due to the ineffectiveness of systemic chemotherapy and local radiation therapies [27, 28]. Recent studies reported that Sorafenib, an oral kinase inhibitor, improved the OS and life quality of HCC patients [29-31]. However, intrinsic or acquired Sorafenib resistance in tumor tissue restricts the effect of this promising approach [2931 ]. On the other hand, local-ablative therapy has becoming a new hope for patients suffering from unresectable HCC. RFA is widely used to treat advanced HCC patients, as it presents better therapeutic outcomes compared to other local ablative methods [32]. Nevertheless, there is not an effective indicator of post-RFA prognosis. 


\begin{tabular}{|c|c|c|c|}
\hline & \multicolumn{2}{|c|}{ MEIS-1 protein level } & \multirow[b]{2}{*}{$\boldsymbol{P}$} \\
\hline & High $(n=43)$ & Low $(n=38)$ & \\
\hline \multirow[t]{2}{*}{ TTP } & $9.0(\mathrm{M})$ & $6.0(\mathrm{M})$ & $<0.001$ \\
\hline & $6.8-11.3(\mathrm{M})$ & 4.6-7.4 (M) & \\
\hline \multirow[t]{2}{*}{ OS } & $14.0(\mathrm{M})$ & $11.0(\mathrm{M})$ & 0.212 \\
\hline & $8.7-19.3(\mathrm{M})$ & $9.4-12.6(\mathrm{M})$ & \\
\hline Overall response rate $(\mathrm{CR}+\mathrm{PR})$ & $17(39.53 \%)$ & $6(15.79 \%)$ & 0.031 \\
\hline Disease control rate $(\mathrm{CR}+\mathrm{PR}+\mathrm{SD})$ & $29(67.44 \%)$ & $16(42.10 \%)$ & 0.022 \\
\hline
\end{tabular}

TTP: time to progress; OS: overall survival; PR: partial remission; CR: complete remission; SD: stable of disease; M: months.
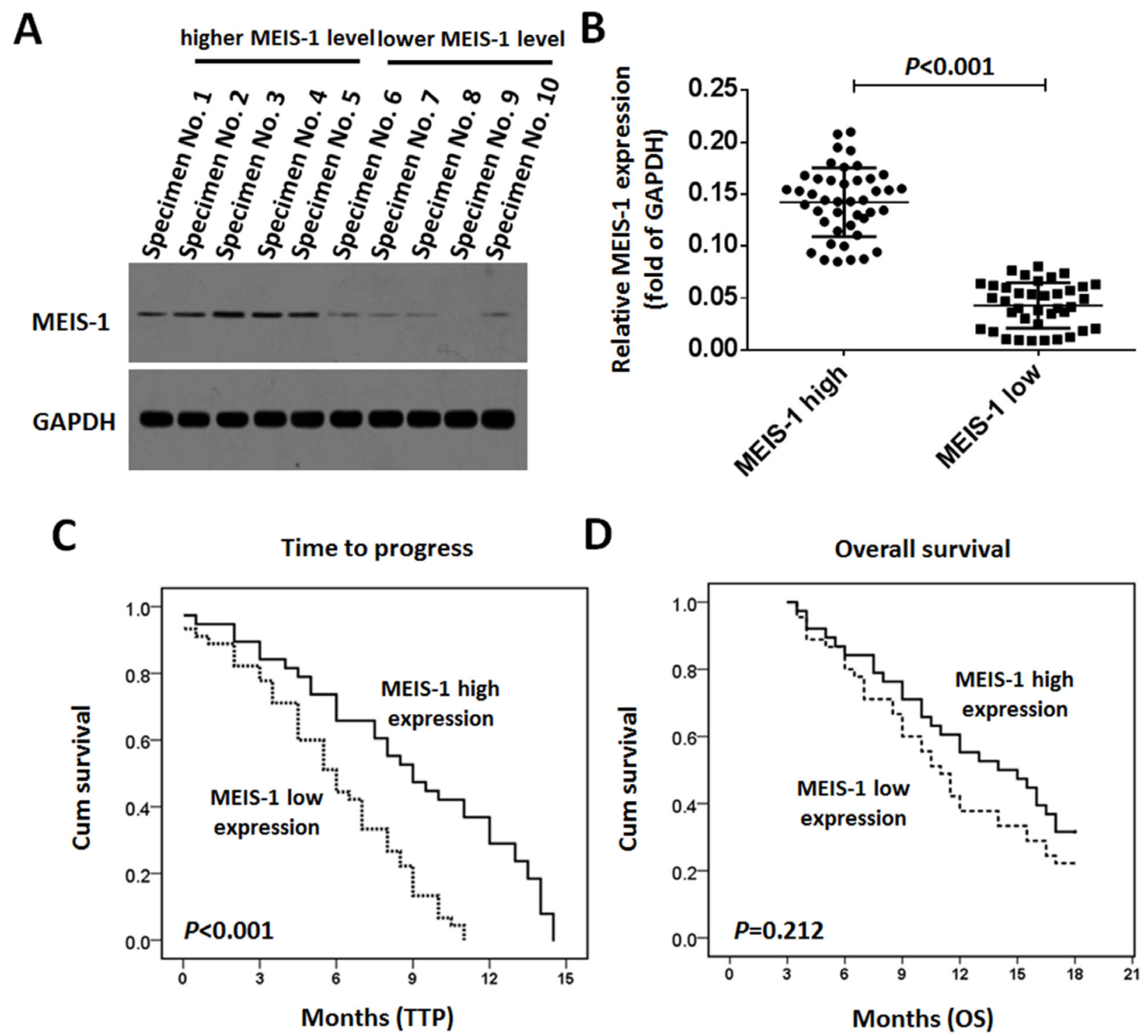

Figure 1: Expression of MEIS-1 and post-RFA outcomes of advanced HCCs. The protein level of MEIS-1 in HCC clinical specimens was identified by a Western blot. (A) Representative photograph of MEIS-1 expression in clinical specimens. Tissue No. 1 to No. 5 indicated MEIS-1 high group, and No. 6 to No. 10 indicated the MEIS-1 low group. (B) Scatter diagram showing the intratumor levels and relative protein levels of MESI-1 in the two patient groups. (C) Kaplan-Meier estimates of the TTP in the two patient groups $(P<0.001)$. (D) D: Kaplan-Meier estimates of OS times in the two patient groups $(P=0.212)$. 
Table 2: Baseline clinical data of 81 patients with advanced HCC

\begin{tabular}{lc}
\hline Presentation & Case (\%) \\
\hline Median age, yr (range) & $49(28-67)$ \\
Gender, male (\%) & $68(83.95 \%)$ \\
Aetiology (\%) & $71(87.65 \%)$ \\
$\quad$ HBV positive & $10(12.35 \%)$ \\
$\quad$ HCV positive & \\
ECOG PS (\%) & $31(38.27 \%)$ \\
0 & $46(56.79 \%)$ \\
1 & $4(4.94 \%)$ \\
2 & \\
AFP (\%) & $17(20.99 \%)$ \\
$\quad$ Normal & $64(79.01 \%)$ \\
Elevated & $32(39.50 \%)$ \\
extrahepatic metastasis (\%) & $39(48.14 \%)$ \\
LN metastasis (\%) & $43(53.08 \%)$ \\
Portal vein invasion (\%) & \\
Chilg-Pugh (\%) & $69(85.18 \%)$ \\
$\quad$ A & $12(14.82 \%)$ \\
B & $1.4(1-3.0)$ \\
Median size of index tumor, cm (range) & $2(1-3)$ \\
Median number of index tumors & \\
Differentiation & $10(12.34 \%)$ \\
Well & $44(54.32 \%)$ \\
Moderately & $27(33.33 \%)$ \\
Poorly & None \\
\hline
\end{tabular}

MEIS-1 play a critical role in several important physiological processes, such as organ development and stem cell differentiation $[33,34]$. It also participates in the development and progression of cancers. For example, aberrant expression of MEIS-1 promoted the development of acute myeloid leukemia [15-19, 35]. However, MEIS-1 has been reported as a negative regulator of some other cancers, such as non-small-cell lung cancer, esophageal squamous cell carcinomas, clear cell renal cell carcinomas and prostate cancer [22-25]. In these studies, the authors proposed that MEIS-1 inhibits tumor cell proliferation and induces cell cycle arrest [22-25]. In the present study, the patients with high MEIS-1 expression show better postRFA outcomes than those with low MEIS- 1 expression. The median TTP was also longer in the high MEIS1 group than in the low MEIS-1 group. Furthermore, the CER and CDR of the patients with high MEIS-1 expression were better than those of the patients with low MEIS-1 expression. These results indicated that MEIS1 's expression level indicates the anti-tumor effect and prognosis of RFA therapy.
RFA is one of the most suitable treatment option for advanced-stage HCC, particularly when a patient's liver functional reserve precludes radiotherapy. However, HCC can recur after RFA, and the phenotype, e.g. Epithelialmesenchymal transition, of the tumor cells often changes [36]. Previous research suggested that incomplete ablation in RFA may induce cellular stress and lead to pathological changes $[37,38]$. Zhu et al. suggested that overexpression of MEIS- 1 inhibits the EMT process and decreases the expression of pro-survival genes in clear cell renal cell carcinomas [25]. Yasui et al. [26] indicated that MEIS-1 may be a suppressor of TGF $\beta$ signaling pathway, which is one of the foremost mediators of EMT. TGF $\beta /$ Smad signaling pathway plays a crucial role in tumorigenesis and tumor development, included HCC $[39,40]$. It has been previously reported that TGF $\beta / \mathrm{Smad}$ can be a tumor suppressor and mediate the expression of tumor suppressor p15 and p21 [41-44]. Zhou et al. showed that Smad3 can sensitize HCC cells to cisplatin treatment by repressing Akt phosphorylation [44]. At same time, other papers also reported that TGF $\beta / \mathrm{Smad}$ 
pathway may facilitate tumor growth [45-47]. It is well known that TGF $\beta /$ Smad pathway plays a central role in EMT process [48].

In the present study, we established a subcutaneous tumor model and then performed RFA at $65-70^{\circ} \mathrm{C}$ for $3-5$ min to attenuate the growth of HCCs. Overexpression of MEIS-1 enhanced the anti-tumor effect of RFA. In the future, in addition to RFA treatment, anti-tumor agents could be injected into tumors to mimic TACE. In addition, intrahepatic growth of HCC cells in nude mice could be achieved by directly ablate the lesion in liver using abdominal surgeries in mice. Local ablation of intrahepatic HCC by RFA could also be performed in some larger animals, e.g. immunodeficient rat, guided by small animal molecular imaging system, e.g. small animal ultrasound systems.

\section{MATERIALS AND METHODS}

\section{Patients}

This prospective study consisted of 81 consecutive patients who underwent RFA between April 2014 and
May 2016, and the baseline clinical data of patients with advanced HCC were shown in Table 2. The inclusion criteria were as follows [7, 49-51]: (A) a diagnosis of HCC and stage B or C unresectable cancer; (B) the presence of portal hypertension and Child's class A or B cirrhosis according to endoscopy or imaging; (C) a life expectancy of at least 12 weeks according to the clinical presentation; (D) Eastern Cooperative Oncology Group performance status 0,1 , or 2; and (E) histological grade of HCC differentiation classed as well differentiated, intermediately differentiated, or poorly differentiated according to the criteria of Edmondson. The collection of the HCC specimens and study protocol were approved by the Ethics Committee of the 302nd Hospital, and informed consent was obtained from all the patients.

None of the HCC patients had received any prior treatment. Clinical specimens were obtained by a puncture biopsy using a coaxial needle (Cat. no.: MCXS1815BP, RITA Company, Crystal Lake, IL, USA) immediately after the RFA treatment. The primary endpoint was the time to progression (TTP) post-RFA, and the secondary endpoint was overall survival (OS). The association of the protein expression of MEIS-1 with post-RFA OS and TTP was assessed in the same cohort of patients. The efficacy of

A

MEIS-1
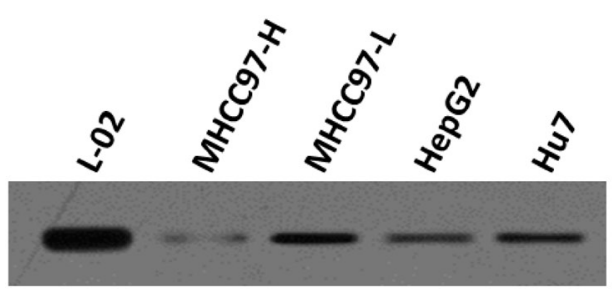

GAPDH
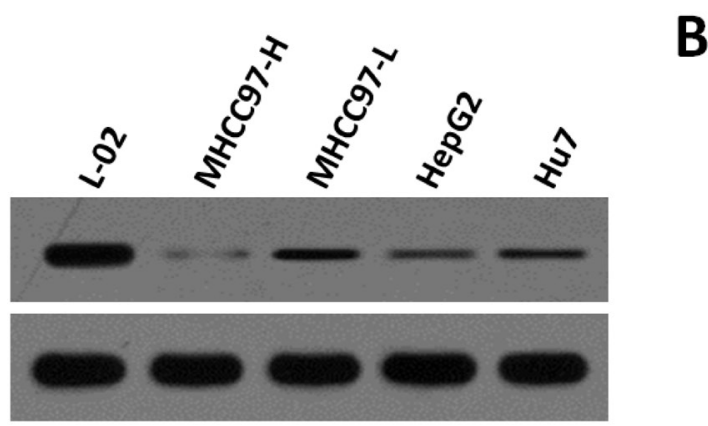

B

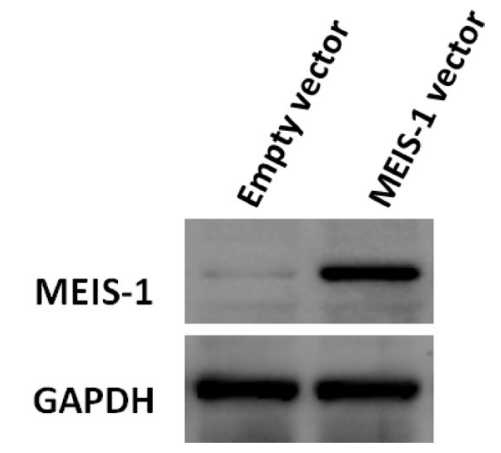

C

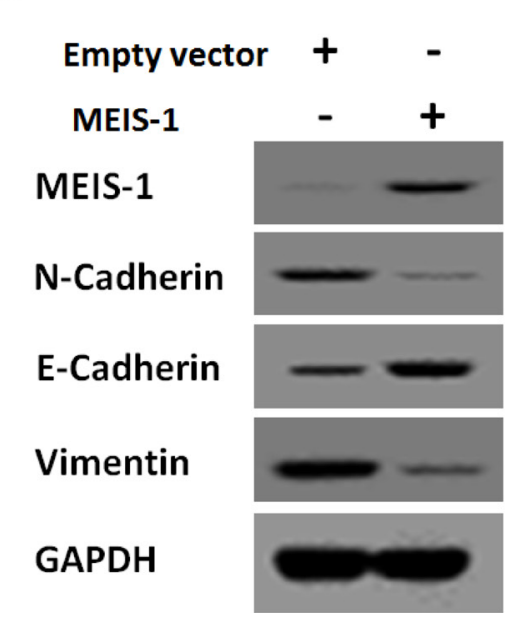

D

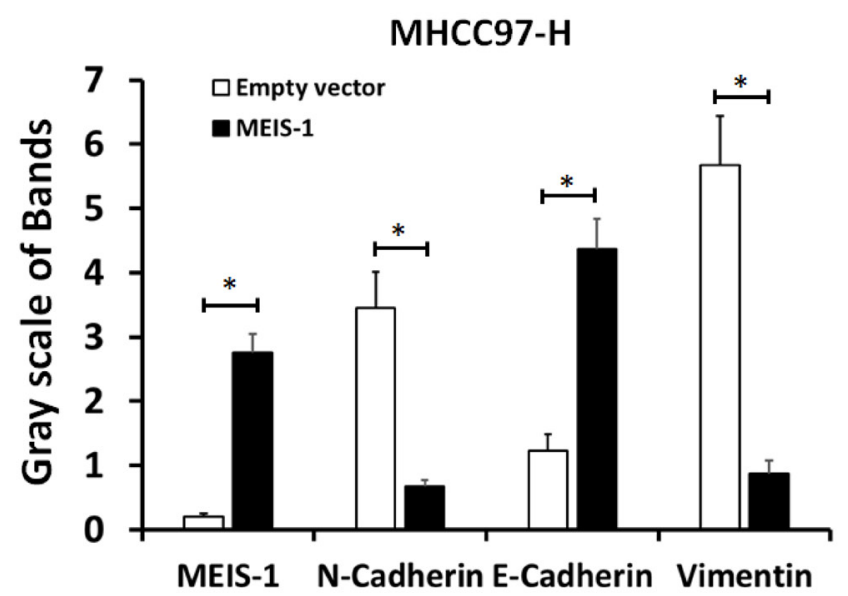

Figure 2: MEIS-1 inhibits the epithelial-mesenchymal transition (EMT) of MHCC97-H cells. (A) The protein level of MESI-1 was identified in a hepatic nontumor cell line (L-02) and HCC cells (HepG2, MHCC97-H, MHCC97-L, and Hu7). (B) MHCC97-H cells infected with an empty vector or MEIS-1 were harvested and analyzed by a western blot. (C, D) The Protein level of MEIS-1, E-cadherin, N-Cadherin or Vimentin was identified by its antibody. 
A

Control

MEIS-1

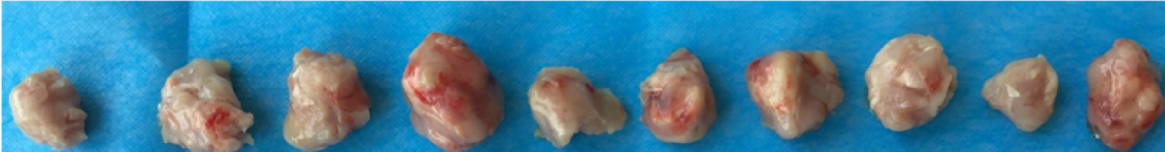

RFA

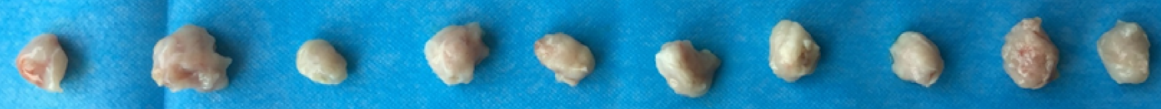

MEIS-1 + RFA

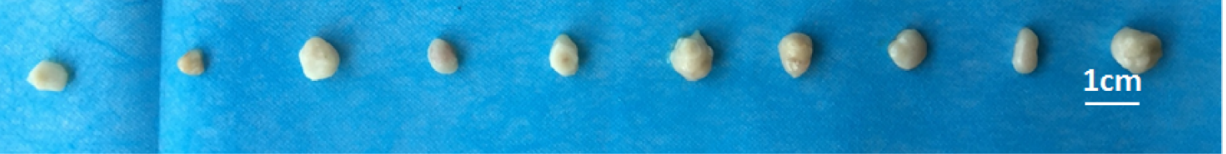

B

MHCC97-H

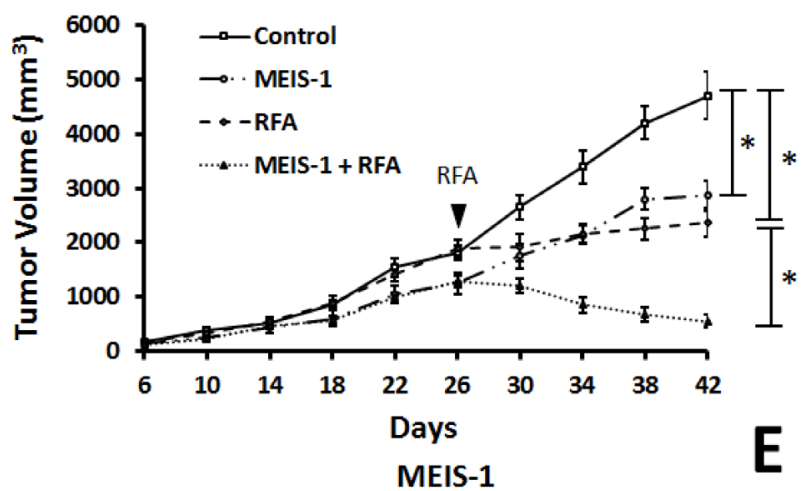

C

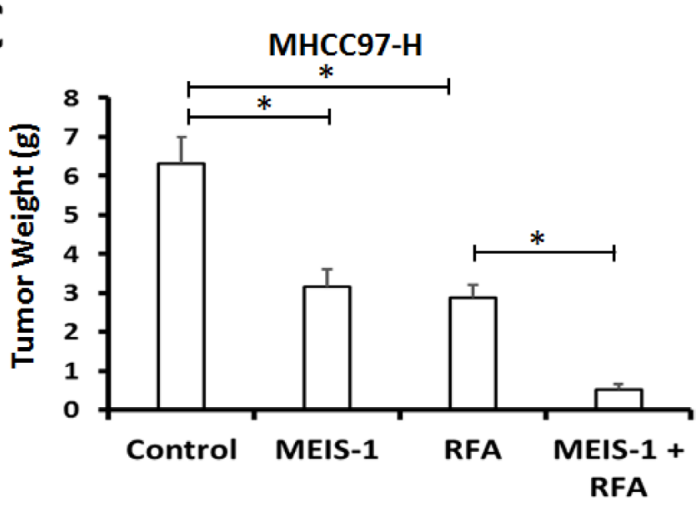

D

MEIS-1

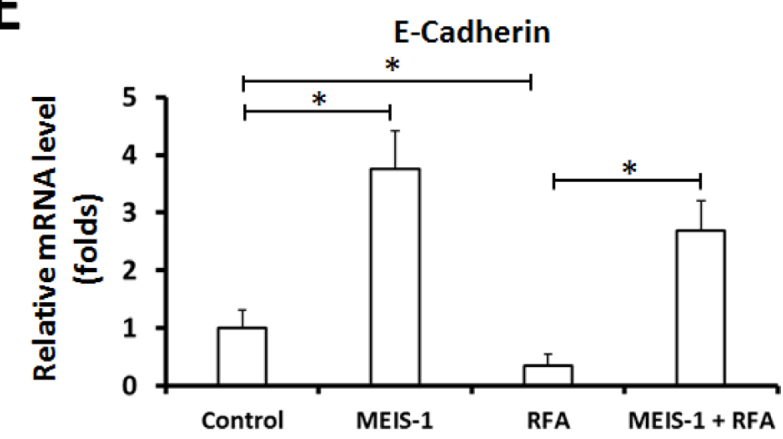

F

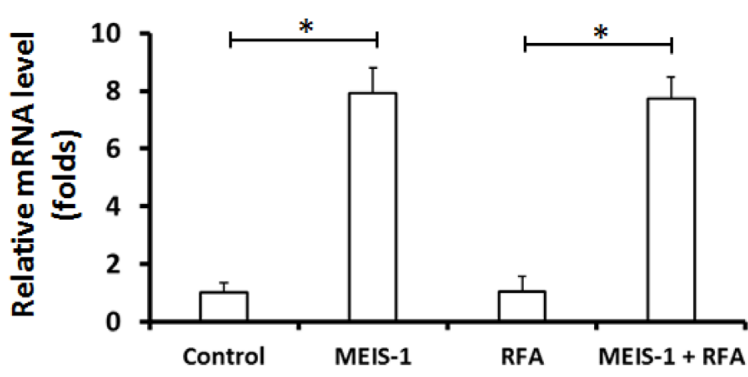

$\mathbf{G}$
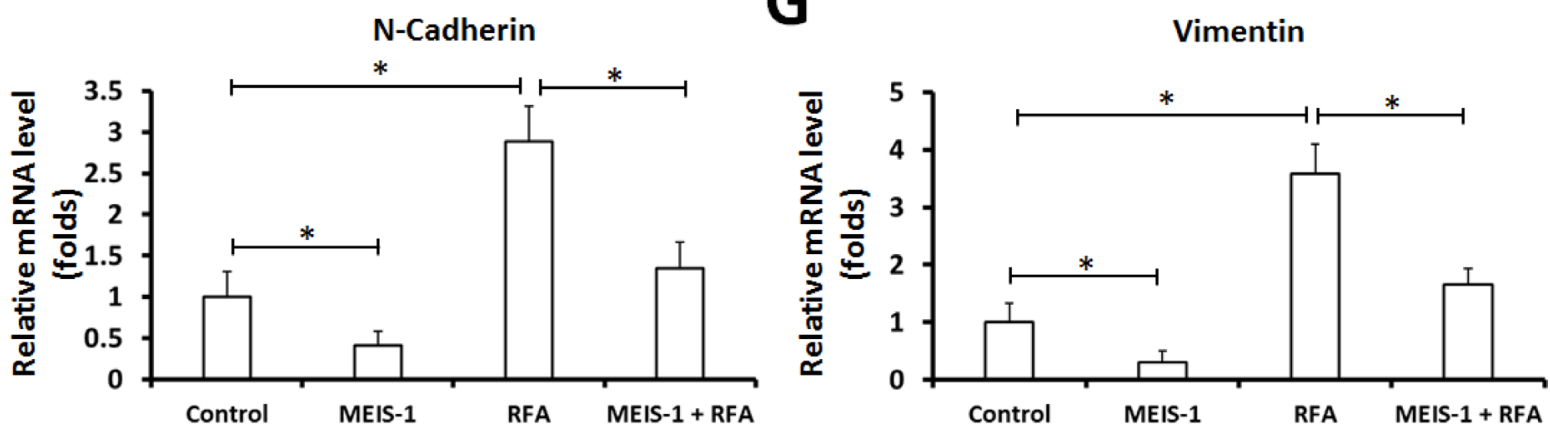

Figure 3: Impact of overexpression of MEIS-1 on subcutaneous growth of HCC cells in RFA-treated nude mice. (A) MHCC97-H cells infected with an empty vector or MEIS-1 were injected into nude mice. When the tumoral volume reached 1000-1200 $\mathrm{mm}^{3}$, RFA was performed. Tumoral growth was defined as the tumoral volume $(\mathbf{B})$ and tumoral weight $(\mathbf{C})$. The relative mRNA level of MEIS-1 (D), E-cadherin $(\mathbf{E})$, N-Cadherin $(\mathbf{F})$ or Vimentin $(\mathbf{G})$ in tumors was shown as mean mean \pm SD. ${ }^{*} P<0.05$. 
RFA was based on the clinical efficacy response (CER)/ overall response rate or disease-control rate (DCR), in accordance with the protocols described in our previous work [7, 51]. The overall response rate was defined as: complete response $(\mathrm{CR})+$ partial response $(\mathrm{PR})[7,51]$. The disease-control ate was defined as: $\mathrm{CR}+\mathrm{PR}+$ stable disease (SD) [7, 51].

\section{Cell culture and Western blot analysis}

A hepatic nontumor cell line, L-02, and HCC cell lines (HepG2, MHCC97-H, MHCC97-L, and Hu7) were cultured in Dulbecco's modified Eagle medium (DMEM) with $10 \%$ fetal bovine serum at $37^{\circ} \mathrm{C}$ in an atmosphere of $5 \% \mathrm{CO}_{2}[51,52]$. Tetracycline (Cat. no.: S2574) was purchased from Sellck Corporation, Houston, Texas, USA. An empty vector adenovirus and MEIS-1 were purchased from Vigene Company (Jinan, Shandong, China). A TETon Lentivirus of MEIS-1 was generated and prepared by Vigene Company (Jinan, Shandong, China). Cells were harvested for Western blot analysis. Total protein was extracted from cells or clinical specimens and subjected to sodium dodecyl sulfate polyacrylamide gel electrophoresis. The proteins were then transferred to a polyvinylidene fluoride film. Next, the blots were blocked by $5 \%$ bovine serum albumin and incubated with the
A
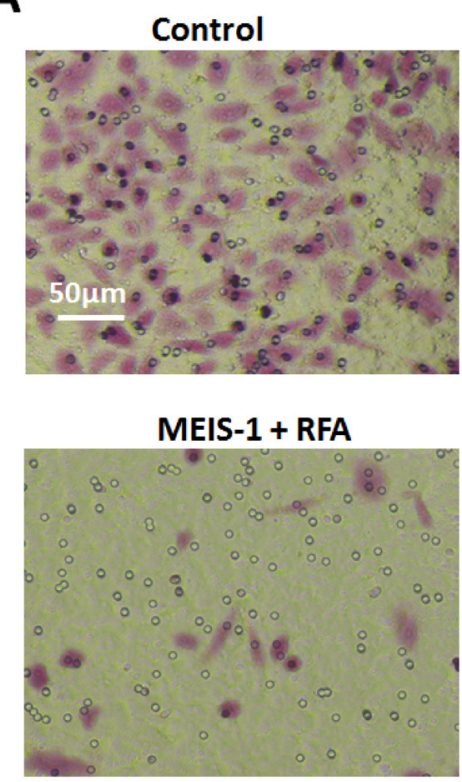

B

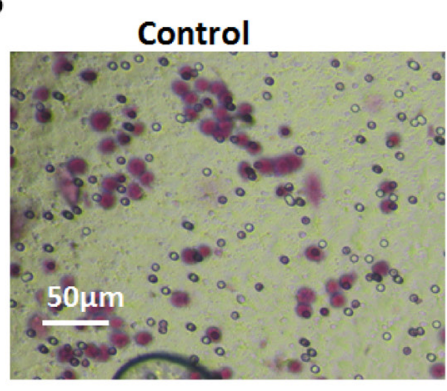

MEIS-1 + RFA

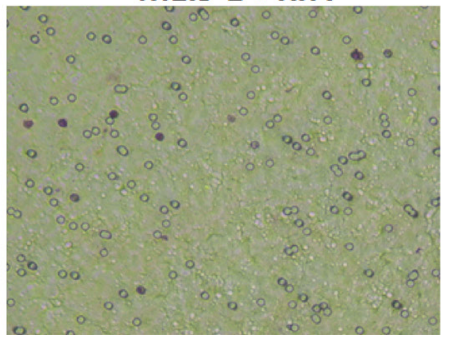

MEIS-1
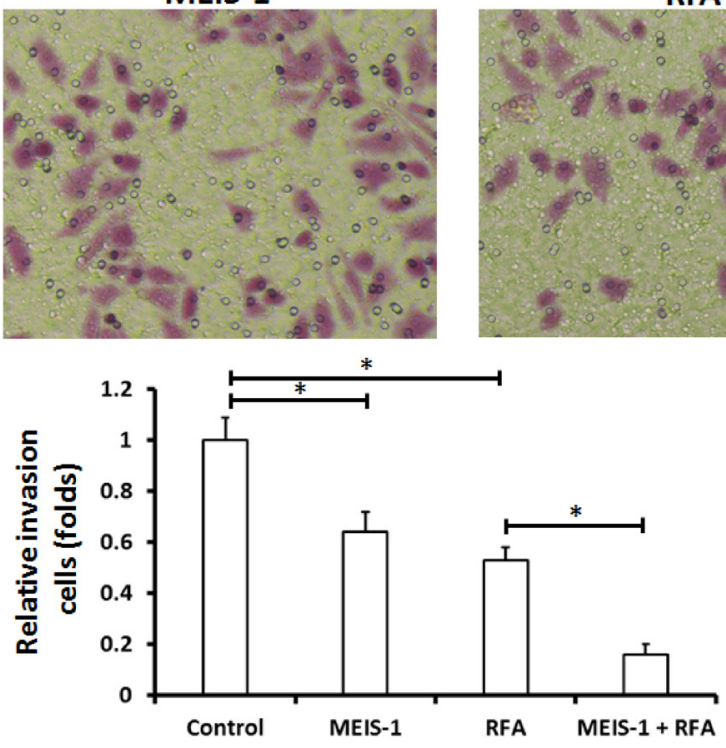

MEIS-1
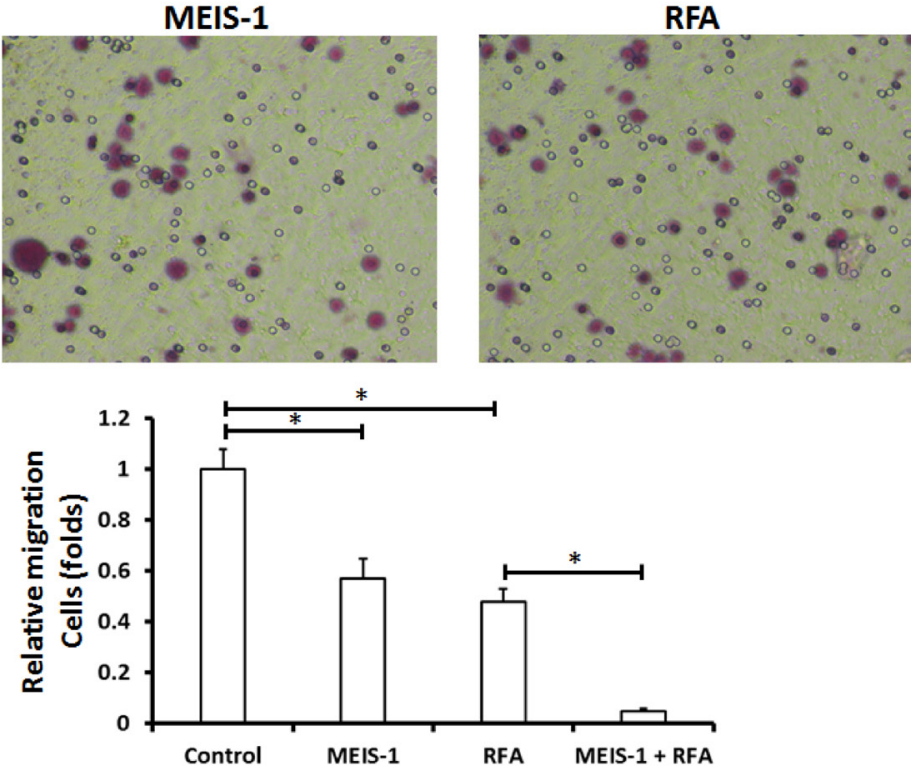

Figure 4: In vitro invasion or migration of cells separated from subcutaneous tumors. The subcutaneous tumors described in Figure 3 were harvested. Then, single cells were separated from the tumors and analyzed using a transwell experiment. The in vitro invasion (A) or migration (B) was shown as representative photographs or mean \pm SD. ${ }^{*} P<0.05$ 
primary antibody anti-MEIS-1 immunoglobulin G (IgG) (Cat. no.: sc-101850, Santa Cruz, USA) in a 1:2000 dilution, anti-E-Cadherin immunoglobulin G (IgG) (Cat. no.: sc-71009, Santa Cruz, USA) in a 1:5000 dilution, antiN-Cadherin immunoglobulin G (IgG) (Cat. no.: sc-59987, Santa Cruz, USA) in a 1:1000 dilution, anti-Vimentin immunoglobulin G (IgG) (Cat. no.: sc-73258, Santa Cruz, USA) in a 1:1000 dilution or anti-glyceraldehyde3-phosphate dehydrogenase (GAPDH) IgG (Cat. no.: sc-47724, Santa Cruz, USA) in a 1:5000 dilution. After washing three times in tris-buffered saline, the blots were incubated with a secondary antibody (1:5000 dilution) and developed by the addition of enhanced chemiluminescence reagents (Qiangen, Beijing, China) and X-ray film exposure. The quantitative protein level of MEIS-1 was determined by gray-scanning analysis using Alpha Innotech analysis software (San Leandro, CA, USA). The protein level of MEIS-1 was normalized to that of a loading control (GAPDH). What was calculated using the following formula: gray scale of MEIS-1 band)/(gray scale of GAPDH).

\section{RFA treatment}

A multipolar 15 cm-long RFA needle (Cat. no.: UniBlate 700-103597, RITA Company, Crystal Lake, IL, USA), with a maximum ablation diameter of $5 \mathrm{~cm}$ was used in all cases. Percutaneous RFA was performed using

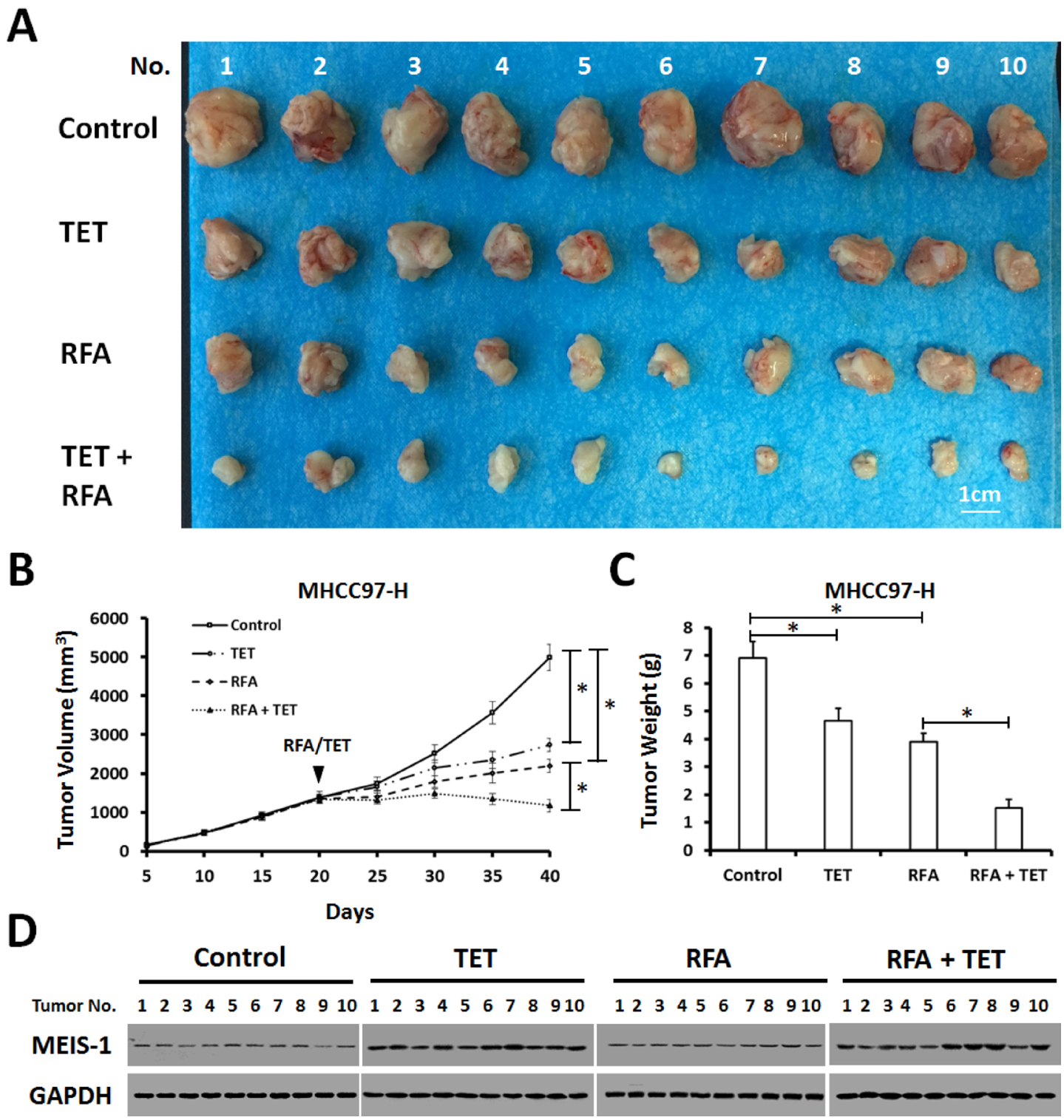

Figure 5: Impact of overexpression of MEIS-1 on subcutaneous growth of HCC cells in RFA-treated nude mice. (A) MHCC97-H cells infected with an empty vector or TET-on-MEIS-1 were injected into nude mice. When the tumoral volume reached 1000$1200 \mathrm{~mm}^{3}$, RFA was performed. Next, mice were received solvent control or tetracycline per day. The tumor growth was defined as the tumoral volume (B) and tumoral weight (C). (D) The expression of MEIS-1 in tumor tissues was identified by western blot via its antibody. 
a radiofrequency therapy instrument (Cat. no.: RITA Model 1500X, RITA Company, Crystal Lake, IL, USA), with guidance provided by computed tomography (CT) scanning. The RFA needle was inserted in the direction of the tumor, and CT scanning was used to confirm the position of the RFA needle. Ablation started once the needle reached the required position. The ablation time was $15-20 \mathrm{~min}$, and the temperature setting was $105^{\circ} \mathrm{C}$.

\section{Animal experiments}

All the animal experiments were reviewed and approved by the Institutional Animal Care and Use
Committee of the 302nd Hospital, People's Liberation Army of China. Nude SCID (severe combined immune deficiency) mice aged 4-6 weeks were purchased from SiBei-Fu Biotechnology Corporation, Beijing China. Figure 7 shows the workflow of the animal experiments.

To produce a subcutaneous tumor model [53-55], MHCC97-H cells infected with a control or MEIS-1 virus vector were injected into nude mice $\left(1 \times 10^{6}\right.$ cells per animal). After 4-6 weeks (26 days), the tumoral volume had reached almost $1200 \mathrm{~mm}^{3}$. RFA of the subcutaneous tumors was performed using a thyroid ablation needle (Cat. no.: UniBlate 700-103587 17G, RITA Company). The ablation time was 3-5 $\mathrm{min}$, and the temperature

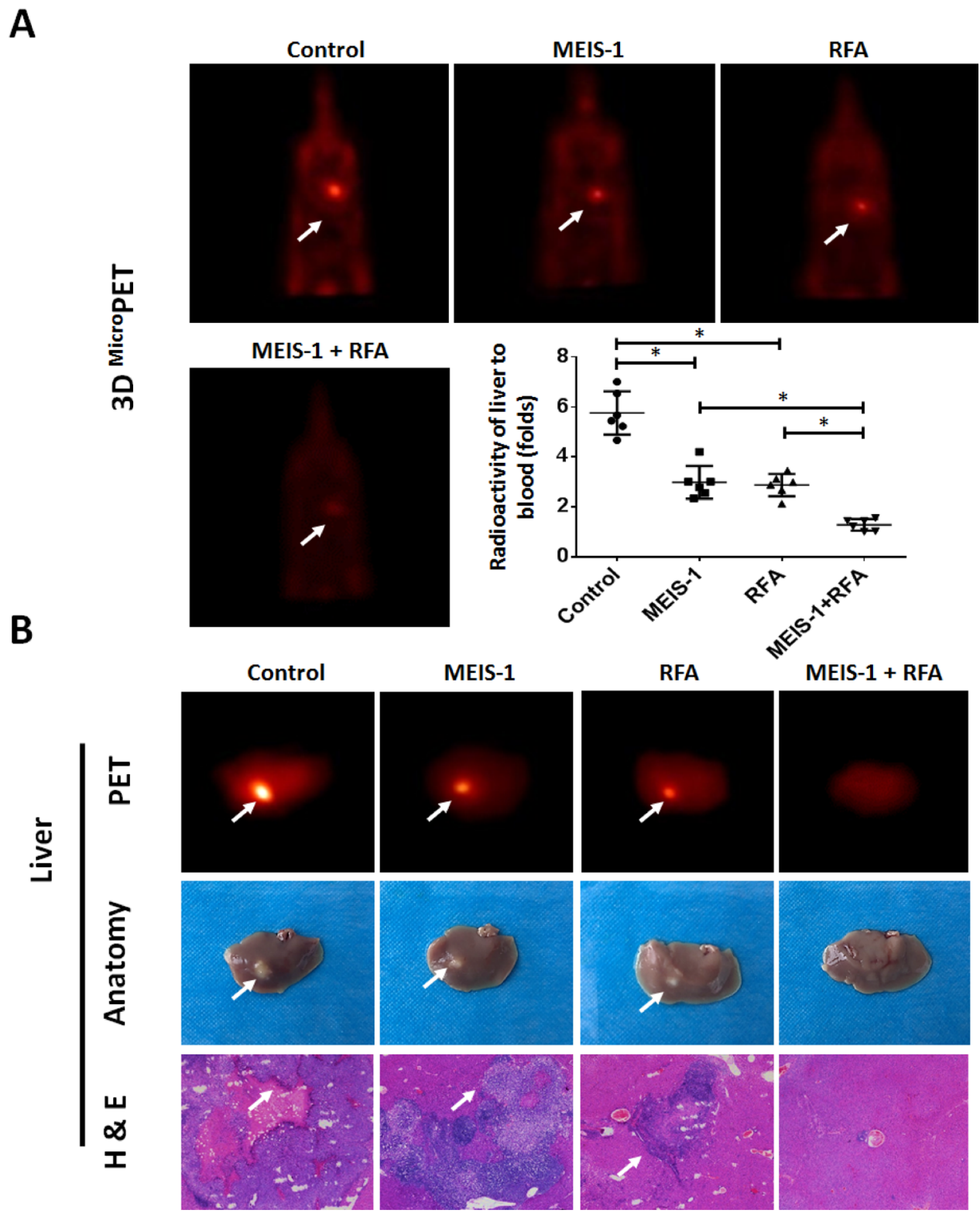

Figure 6: Intrahepatic growth of cells separated from subcutaneous tumors. The subcutaneous tumors described in Figure 3 were harvested. Then, single cells were separated from the tumors and injected into the right lobe of the liver. After 4-8 weeks, ${ }^{18} \mathrm{~F}-\mathrm{FDG} /$ PET images $(n=6)$ were obtained (A). (B) The results of the PET/CT were confirmed by the radioactivity of ablated livers and H\&E staining. The arrows indicate intrahepatic tumor nodules. ${ }^{*} P<0.05$. 
setting was $65-70^{\circ} \mathrm{C}$. After the RFA treatment, the tumoral volume was calculated every 4 days using the following formula: width ${ }^{2} \times$ length/2. Tumors were harvested 16 days after the RFA treatment, and their weights were measured.

To produce a liver in situ tumor model [56-58], HCC cells were separated from subcutaneous tumors formed by MHCC97-H cells and directly inoculated into the right lobe of the liver $\left(1 \times 10^{5}\right.$ cells per animal $)$. After $4-8$ weeks, nude mice were injected intravenously with $100 \mu \mathrm{Ci}$ of $18 \mathrm{~F}$ radiolabeled fluorodeoxyglucose $\left({ }^{18} \mathrm{~F}-\mathrm{FDG}\right)$, and the animals were examined using a positron emission tomography/ computed tomography (PET/CT) scanner (Philips Corp., Holland). Two-minute CT and 10-min PET scans were performed 45 min after the FDG injection. A NaI (Tl) well counter (China Atom Corp., Beijing China) was used to measure the radioactivity of organs (liver) and blood.

\section{qPCR}

The qPCR (Quantitative reverse-transcription PCR) was performed following the methods descripted by Feng et al., 2015 [59]. Briefly, RNA samples were extracted from subcutaneous tumor by PARISTM Kit (Applied Biosystems, Foster City, CA, USA) and reverse-transcribed to cDNA by a Multiscribe ${ }^{\mathrm{TM}}$ Reverse Transcriptase kit (Applied Biosystems, Foster City, CA, USA) according to the manufacturer's instructions. The mRNAs level of MEIS-1, E-Cadherin, $\mathrm{N}$-Cadherin or Vimentin was examined by qPCR. The sequences of the primers used were presented in Supplementary Table 1 [60].

\section{Transwell analysis}

MHCC97-H cells were injected into nude mice to produce subcutaneous tumors. Subsequently, the tumors were divided into an RFA-treatment group and a non-RFA treatment group. Next, single cells (3000 per well) were separated from the subcutaneous tumors and were analyzed by transwell assays performed in 24-well plates chamber (Corning, Lowell, MA, USA) fitted with a polyethylene terephthalate filter membrane with 8 - $\mu$ m pores. The invasion cells or migration cells were measured following the methods descripted by Zhou et al. and Yang et al. [61, 62].

\section{Statistical analysis}

All the statistical analyses were performed using SPSS software (version 16.0). Data are presented as

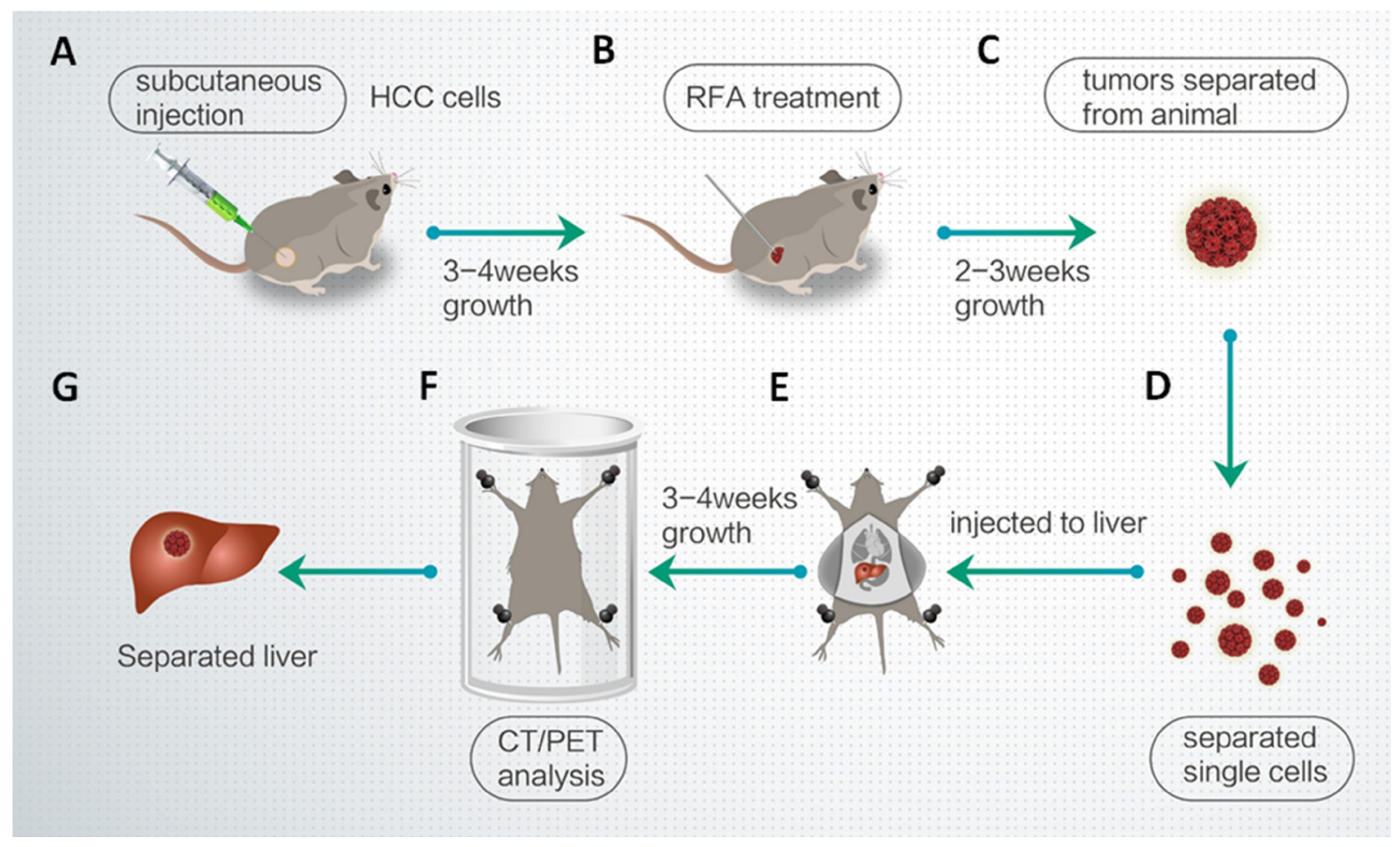

Figure 7: Workflow of the animal experiments. (A) MHCC97-H cells were injected into nude mice. (B) After 3-4 weeks, the subcutaneous tumors were treated with RFA. (C) After 2-3 weeks, the tumors were removed. (D) Single cells were separated from the tumors by tissue-grinding and sieve-filtrating. (E) The cells were then injected into the right lobe of the liver. (F) After 3-4 weeks, intrahepatic HCCs were identified by CT/PET. (G) The liver was anatomized and separated to show the intrahepatic lesions/intrahepatic nodules formed by HCC cells. 
the median and range. The OS rate was estimated by the Kaplan-Meier method, and groups were compared by the log-rank test. Pearson's Chi-square test was used to test the difference between the CER and DCR of the MEIS-1 high and MEIS-1 low groups. In all the analyses, a $P$-value $<0.05$ was considered statistically significant.

\section{CONCLUSIONS}

The endogenous level of MEIS-1 seems to be associated with post-RFA treatment outcomes. The median post-RFA TTP of patients with a low MEIS-1 expression level was significantly shorter than patients with a high MEIS-1 expression level. To validate this, we used rodent tumor growth model. Overexpression of MEIS-1 enhanced the tumor rejection effect of RFA in preventing subcutaneous growth of HCC cells. The findings indicate that MEIS-1 and RFA may exert a synergetic effect, resulting in a reduction in the tumor volume. Our data suggest that the expression level of MEIS-1 may serve as a clinical predictor of post-RFA treatment outcomes in HCC patients.

\section{Abbreviations}

MEIS-1, myeloid ecotropic viral integration site 1; RFA, radiofrequency ablation; $\mathrm{HCC}$, hepatocellular carcinoma; TTP, progression; OS, overall survival; TALE, Triple amino acid loop extension; HD, homeodomain; AML, acute myeloid leukemia; CER, Clinical efficacy response; $\mathrm{CR}$, complete response; $\mathrm{PR}$, partial response; DCR, Disease-control rate; SD, stable disease; PVDF, Polyvinylidene Fluoride; 18F-FDG, 18F radio-labeled fluorodeoxyglucose; NSCLC, non-small-cell lung cancer; ESCC, esophageal squamous cell carcinoma; ccRCC, clear cell renal cell carcinoma; PC, prostate cancer; EMT, Epithelial-mesenchymal transition.

\section{CONFLICTS OF INTEREST}

The authors declare no conflicts of interest.

\section{FUNDING}

This study was supported in part by National Natural Science Foundation of China, No.81471761 and No.81501568; Tianjin Program to Support Science and Technology Research, No.15ZCZDSY00890.

\section{REFERENCES}

1. Wang FS, Fan JG, Zhang Z, Gao B, Wang HY. The global burden of liver disease: the major impact of China. Hepatology. 2014; 60:2099-2108
2. Qiu J, Peng B, Tang Y, Qian Y, Guo P, Li M, Luo J, Chen B, Tang H, Lu C, Cai M, Ke Z, He W, et al. CpG Methylation Signature Predicts Recurrence in Early-Stage Hepatocellular Carcinoma: Results From a Multicenter Study. J Clin Oncol. 2017; 35:734-742

3. Chan SL, Wong VW, Qin S, Chan HL. Infection and Cancer: The Case of Hepatitis B. J Clin Oncol. 2016; 34:83-90

4. Tai WM, Yong WP, Lim C, Low LS, Tham CK, Koh TS, Ng QS, Wang WW, Wang LZ, Hartano S, Thng CH, Huynh H, Lim KT, et al. A phase Ib study of selumetinib (AZD6244, ARRY-142886) in combination with sorafenib in advanced hepatocellular carcinoma (HCC). Ann Oncol. 2016; 27:2210-2215.

5. Ikeda M, Shimizu S, Sato T, Morimoto M, Kojima Y, Inaba Y, Hagihara A, Kudo M, Nakamori S, Kaneko S, Sugimoto R, Tahara T, Ohmura T, et al. Sorafenib plus hepatic arterial infusion chemotherapy with cisplatin versus sorafenib for advanced hepatocellular carcinoma: randomized phase II trial. Ann Oncol. 2016; 27:2090-96.

6. Zhu YJ, Zheng B, Wang HY, Chen L. New knowledge of the mechanisms of sorafenib resistance in liver cancer. Acta Pharmacol Sin. 2017; 38:614-622.

7. Wang C, Wang H, Yang W, Hu K, Xie H, Hu KQ, Bai W, Dong Z, Lu Y, Zeng Z, Lou M, Wang H, Gao X, et al. Multicenter randomized controlled trial of percutaneous cryoablation versus radiofrequency ablation in hepatocellular carcinoma. Hepatology. 2015; 61:1579-1590.

8. Yang DJ, Luo KL, Liu H, Cai B, Tao GQ, Su XF, Hou XJ, Ye F, Li XY, Tian ZQ. Meta-analysis of transcatheter arterial chemoembolization plus radiofrequency ablation versus transcatheter arterial chemoembolization alone for hepatocellular carcinoma. Oncotarget. 2017; 8:2960-70. https://doi.org/10.18632/oncotarget.13813.

9. Wang W, Bai W, Wang E, Zhao Y, Liu L, Yang M, Cai H, Xia D, Zhang L, Niu J, Yin Z, Zhang Z, Fan D, et al. mRECIST response combined with sorafenib-related adverse events is superior to either criterion alone in predicting survival in HCC patients treated with TACE plus sorafenib. Int J Cancer. 2017; 140:390-399

10. Cui J, Wang N, Zhao H, Jin H, Wang G, Niu C, Terunuma $\mathrm{H}, \mathrm{He} \mathrm{H}, \mathrm{Li}$ W. Combination of radiofrequency ablation and sequential cellular immunotherapy improves progressionfree survival for patients with hepatocellular carcinoma. Int J Cancer. 2014; 134:342-351.

11. Lee MW, Raman SS, Asvadi NH, Siripongsakun S, Hicks RM, Chen J, Worakitsitisatorn A, McWilliams J, Tong MJ, Finn RS, Agopian VG, Busuttil RW, Lu DSK. Radiofrequency ablation of hepatocellular carcinoma as bridge therapy to liver transplantation: A 10-year intentionto-treat analysis. Hepatology. 2017; 65:1979-1990.

12. Mohr S, Doebele C, Comoglio F, Berg T, Beck J, Bohnenberger H, Alexe G, Corso J, Ströbel P, Wachter A, Beissbarth T, Schnütgen F, Cremer A, et al. Hoxa9 and Meis1 Cooperatively Induce Addiction to Syk Signaling by Suppressing miR-146a in Acute Myeloid Leukemia. Cancer Cell. 2017; 31:549-562.e11. 
13. Cui L, Li M, Feng F, Yang Y, Hang X, Cui J, Gao J. MEIS1 functions as a potential AR negative regulator. Exp Cell Res. 2014; 328:58-68.

14. Su Z, Si W, Li L, Zhou B, Li X, Xu Y, Xu C, Jia H, Wang QK. MiR-144 regulates hematopoiesis and vascular development by targeting meis1 during zebrafish development. Int J Biochem Cell Biol. 2014; 49:53-63.

15. Antosova B, Smolikova J, Klimova L, Lachova J, Bendova M, Kozmikova I, Machon O, Kozmik Z. The Gene Regulatory Network of Lens Induction Is Wired through Meis-Dependent Shadow Enhancers of Pax6. PLoS Genet. 2016; 12:e1006441.

16. Ferreira HJ, Heyn H, Vizoso M, Moutinho C, Vidal E, Gomez A, Martínez-Cardús A, Simó-Riudalbas L, Moran S, Jost E, Esteller M. DNMT3A mutations mediate the epigenetic reactivation of the leukemogenic factor MEIS1 in acute myeloid leukemia. Oncogene. 2016; 35:3079-3082.

17. Adamaki M, Lambrou GI, Athanasiadou A, Vlahopoulos S, Papavassiliou AG, Moschovi M. HOXA9 and MEIS1 gene overexpression in the diagnosis of childhood acute leukemias: Significant correlation with relapse and overall survival. Leuk Res. 2015; 39:874-882.

18. Manachai N, Saito Y, Nakahata S, Bahirvani AG, Osato M, Morishita K. Activation of EVI transcription by the LEF1/ $\beta$-catenin complex with p53-alteration in myeloid blast crisis of chronic myeloid leukemia. Biochem Biophys Res Commun. 2017; 482:994-1000.

19. Ogawara Y, Katsumoto T, Aikawa Y, Shima Y, Kagiyama Y, Soga T, Matsunaga H, Seki T, Araki K, Kitabayashi I. IDH2 and NPM1 Mutations Cooperate to Activate Hoxa9/Meis1 and Hypoxia Pathways in Acute Myeloid Leukemia. Cancer Res. 2015; 75:2005-2016.

20. Mahmoud AI, Kocabas F, Muralidhar SA, Kimura W, Koura AS, Thet S, Porrello ER, Sadek HA. Meis1 regulates postnatal cardiomyocyte cell cycle arrest. Nature. 2013; 497:249-253.

21. Chen JL, Li J, Kiriluk KJ, Rosen AM, Paner GP, Antic T, Lussier YA, Vander Griend DR. Deregulation of a Hox protein regulatory network spanning prostate cancer initiation and progression. Clin Cancer Res. 2012; 18:4291-4302.

22. Xu B, Geerts D, Qian K, Zhang H, Zhu G. Myeloid ecotropic viral integration site 1 (MEIS) 1 involvement in embryonic implantation. Hum Reprod. 2008; 23:1394-1406.

23. Li W, Huang K, Guo H, Cui G. Meis1 regulates proliferation of non-small-cell lung cancer cells. J Thorac Dis. 2014; 6:850-855.

24. Rad A, Farshchian M, Forghanifard MM, Matin MM, Bahrami AR, Geerts D, A'rabi A, Memar B, Abbaszadegan MR. Predicting the molecular role of MEIS1 in esophageal squamous cell carcinoma. Tumour Biol. 2016; 37:1715-1725.

25. Zhu J, Cui L, Xu A, Yin X, Li F, Gao J. MEIS1 inhibits clear cell renal cell carcinoma cells proliferation and in vitro invasion or migration. BMC Cancer. 2017; 17:176.

26. Yasui K, Konishi C, Gen Y, Endo M, Dohi O, Tomie A, Kitaichi T, Yamada N, Iwai N, Nishikawa T, Yamaguchi
K, Moriguchi M, Sumida Y, et al. EVI1, a target gene for amplification at 3q26, antagonizes transforming growth factor- $\beta$-mediated growth inhibition in hepatocellular carcinoma. Cancer Sci. 2015; 106:929-937.

27. Xiao Q, Qu K, Wang C, Kong Y, Liu C, Jiang D, Saiyin H, Jia F, Ni C, Chen T, Zhang Y, Zhang P, Qin W, et al. HDGFrelated protein-3 is required for anchorage-independent survival and chemoresistance in hepatocellular carcinomas. Gut. 2013; 62:440-451.

28. Kim DW, Talati C, Kim R. Hepatocellular carcinoma (HCC): beyond sorafenib-chemotherapy. J Gastrointest Oncol. 2017; 8:256-265.

29. Brown KT, Do RK, Gonen M, Covey AM, Getrajdman GI, Sofocleous CT, Jarnagin WR, D'Angelica MI, Allen PJ, Erinjeri JP, Brody LA, O’Neill GP, Johnson KN, et al. Randomized Trial of Hepatic Artery Embolization for Hepatocellular Carcinoma Using DoxorubicinEluting Microspheres Compared With Embolization With Microspheres Alone. J Clin Oncol. 2016; 34:2046-2053.

30. Abou-Alfa GK, Puig O, Daniele B, Kudo M, Merle P, Park JW, Ross P, Peron JM, Ebert O, Chan S, Poon TP, Colombo M, Okusaka T, et al. Randomized phase II placebo controlled study of codrituzumab in previously treated patients with advanced hepatocellular carcinoma. J Hepatol. 2016; 65:289-295.

31. Cheng AL, Thongprasert S, Lim HY, Sukeepaisarnjaroen W, Yang TS, Wu CC, Chao Y, Chan SL, Kudo M, Ikeda M, Kang YK, Pan H, Numata K, et al. Randomized, open-label phase 2 study comparing frontline dovitinib versus sorafenib in patients with advanced hepatocellular carcinoma. Hepatology. 2016; 64:774-784.

32. Hocquelet A, Seror O, Blanc JF, Frulio N, Salut C, Nault JC, Trillaud H. Transarterial chemoembolization for early stage hepatocellular carcinoma decrease local tumor control and overall survival compared to radiofrequency ablation. Oncotarget. 2017; 8:32190-200. https://doi.org/10.18632/ oncotarget.12921.

33. Moghbeli M, Rad A, Farshchian M, Taghehchian N, Gholamin M, Abbaszadegan MR. Correlation Between Meis1 and Msi1 in Esophageal Squamous Cell Carcinoma. J Gastrointest Cancer. 2016; 47:273-277.

34. Riedel SS, Haladyna JN, Bezzant M, Stevens B, Pollyea DA, Sinha AU, Armstrong SA, Wei Q, Pollock RM, Daigle SR, Jordan CT, Ernst P, Neff T, et al. MLL1 and DOT1L cooperate with meningioma-1 to induce acute myeloid leukemia. J Clin Invest. 2016; 126:1438-1450.

35. Dardaei L, Penkov D, Mathiasen L, Bora P, Morelli MJ, Blasi F. Tumorigenesis by Meis1 overexpression is accompanied by a change of DNA target-sequence specificity which allows binding to the AP-1 element. Oncotarget. 2015; 6:25175-87. https://doi.org/10.18632/oncotarget.4488.

36. Huang M, Chen C, Geng J, Han D, Wang T, Xie T, Wang L, Wang Y, Wang C, Lei Z, Chu X. Targeting KDM1A attenuates $\mathrm{Wnt} / \beta$-catenin signaling pathway to eliminate sorafenib-resistant stem-like cells in hepatocellular carcinoma. Cancer Lett. 2017; 398:12-21. 
37. Ikemoto T, Shimada M, Yamada S. Pathophysiology of recurrent hepatocellular carcinoma after radiofrequency ablation. Hepatol Res. 2017; 47:23-30.

38. Dong S, Kong L, Kong F, Kong J, Gao J, Ji L, Pan B, Chen L, Zheng L, Sun W. Sorafenib suppresses the epithelialmesenchymal transition of hepatocellular carcinoma cells after insufficient radiofrequency ablation. BMC Cancer. 2015; 15:939.

39. Gulei D, Mehterov N, Ling H, Stanta G, Braicu C, Berindan-Neagoe I. The "good-cop bad-cop" TGF-beta role in breast cancer modulated by non-coding RNAs. Biochim Biophys Acta. 2017; 1861:1661-1675.

40. Zhang J, Wang QZ, Zhao SH, Ji X, Qiu J, Wang J, Zhou Y, Cai Q, Zhang J, Gao HQ. Astaxanthin attenuated pressure overload-induced cardiac dysfunction and myocardial fibrosis: Partially by activating SIRT1. Biochim Biophys Acta. 2017; 1861:1715-1728.

41. Ding L, Wang Z, Yan J, Yang X, Liu A, Qiu W, Zhu J, Han J, Zhang H, Lin J, Cheng L, Qin X, Niu C, et al. Human four-and-a-half LIM family members suppress tumor cell growth through a TGF-beta-like signaling pathway. J Clin Invest. 2009; 119:349-361.

42. Sun Y, Ding L, Zhang H, Han J, Yang X, Yan J, Zhu Y, Li J, Song H, Ye Q. Potentiation of Smad-mediated transcriptional activation by the RNA-binding protein RBPMS. Nucleic Acids Res. 2006; 34:6314-6326.

43. Ali A, Zhang P, Liangfang Y, Wenshe S, Wang H, Lin X, Dai Y, Feng XH, Moses R, Wang D, Li X, Xiao J. KLF17 empowers TGF- $\beta /$ Smad signaling by targeting Smad3dependent pathway to suppress tumor growth and metastasis during cancer progression. Cell Death Dis. 2015; 6:e1681.

44. Zhou HH, Chen L, Liang HF, Li GZ, Zhang BX, Chen XP. Smad3 Sensitizes Hepatocelluar Carcinoma Cells to Cisplatin by Repressing Phosphorylation of AKT. Int J Mol Sci. 2016; 17:E610.

45. Xia W, Lo CM, Poon RY, Cheung TT, Chan AC, Chen L, Yang S, Tsao GS, Wang XQ. Smad inhibitor induces CSC differentiation for effective chemosensitization in cyclin D1- and TGF- $\beta /$ Smad-regulated liver cancer stem cell-like cells. Oncotarget. 2017; 8:38811-24. https://doi. org/10.18632/oncotarget.16402.

46. Chen G, Nakamura I, Dhanasekaran R, Iguchi E, Tolosa EJ, Romecin PA, Vera RE, Almada LL, Miamen AG, Chaiteerakij R, Zhou M, Asiedu MK, Moser CD, et al. Transcriptional Induction of Periostin by a Sulfatase 2-TGF $\beta 1-S M A D$ Signaling Axis Mediates Tumor Angiogenesis in Hepatocellular Carcinoma. Cancer Res. 2017; 77:632-645.

47. Wittmann P, Grubinger M, Gröger C, Huber H, Sieghart W, Peck-Radosavljevic M, Mikulits W. Neuropilin-2 induced by transforming growth factor- $\beta$ augments migration of hepatocellular carcinoma cells. BMC Cancer. 2015 Nov 16; 15:909.

48. Zhou XL, Xu P, Chen HH, Zhao Y, Shen J, Jiang C, Jiang S, Ni SZ, Xu B, Li L. Thalidomide Inhibits TGF- $\beta 1$-induced Epithelial to Mesenchymal Transition in Alveolar Epithelial
Cells via Smad-Dependent and Smad-Independent Signaling Pathways. Sci Rep. 2017; 7:14727.

49. European Association For The Study Of The Liver, European Organisation For Research And Treatment Of Cancer. EASL-EORTC clinical practice guidelines: management of hepatocellular carcinoma. J Hepatol. 2012; 56:908-943.

50. Zhu M, Li M, Wang T, Linghu E, Wu B. MicroRNA-137 represses FBI-1 to inhibit proliferation and in vitro invasion and migration of hepatocellular carcinoma cells. Tumour Biol. 2016; 37:13995-4008.

51. Hou J, Hong Z, Feng F, Chai Y, Zhang Y, Jiang Q, Hu Y, Wu S, Wu Y, Gao X, Chen Q, Wan Y, Bi J, et al. novel chemotherapeutic sensitivity-testing system based on collagen gel droplet embedded 3D-culture methods for hepatocellular carcinoma. BMC Cancer. 2017; 17:729.

52. Chen Y, Feng F, Gao X, Wang C, Sun H, Zhang C, Zeng Z, Lu Y, An L, Qu J, Wang F, Yang Y. MiRNA153 Reduces Effects of Chemotherapeutic Agents or Small Molecular Kinase Inhibitor in HCC Cells. Curr Cancer Drug Targets 2015; 15:176-187.

53. Li L, Kang L, Zhao W, Feng Y, Liu W, Wang T, Mai H, Huang J, Chen S, Liang Y, Han J, Xu X, Ye Q. miR-30a$5 \mathrm{p}$ suppresses breast tumor growth and metastasis through inhibition of LDHA-mediated Warburg effect. Cancer Lett. 2017; 400:89-98.

54. Jia H, Yang Q, Wang T, Cao Y, Jiang QY, Ma HD, Sun HW, Hou MX, Yang YP, Feng F. Rhamnetin induces sensitization of hepatocellular carcinoma cells to a small molecular kinase inhibitor or chemotherapeutic agents. Biochim Biophys Acta. 2016; 1860:1417-1430.

55. An L, Li DD, Chu HX, Zhang Q, Wang CL, Fan YH, Song Q, Ma HD, Feng F, Zhao QC. Terfenadine combined with epirubicin impedes the chemo-resistant human non-small cell lung cancer both in vitro and in vivo through EMT and Notch reversal. Pharmacol Res. 2017; 124:105-115.

56. Chao T, Tai WT, Hung MH, Tsai MH, Chen MH, Chang MJ, Shiau CW, Chen KF. A combination of sorafenib and SC-43 is a synergistic SHP-1 agonist duo to advance hepatocellular carcinoma therapy. Cancer Lett. 2016; 371:205-213.

57. Xu X, Fan Z, Liang C, Li L, Wang L, Liang Y, Wu J, Chang S, Yan Z, Lv Z, Fu J, Liu Y, Jin S, et al. A signature motif in LIM proteins mediates binding to checkpoint proteins and increases tumour radiosensitivity. Nat Commun. 2017; 8:14059.

58. Xu X, Fan Z, Kang L, Han J, Jiang C, Zheng X, Zhu Z, Jiao H, Lin J, Jiang K, Ding L, Zhang H, Cheng L, et al. Hepatitis B virus $\mathrm{X}$ protein represses miRNA-148a to enhance tumorigenesis. J Clin Invest. 2013; 123:630-645.

59. Feng Y, Xu X, Zhang Y, Ding J, Wang Y, Zhang X, Wu Z, Kang L, Liang Y, Zhou L, Song S, Zhao K, Ye Q. HPIP is upregulated in colorectal cancer and regulates colorectal cancer cell proliferation, apoptosis and invasion. Sci Rep. 2015; 5:9429.

60. Mao XW, Xiao JQ, Xu G, Li ZY, Wu HF, Li Y, Zheng YC, Zhang N. CUL4B promotes bladder cancer metastasis and 
induces epithelial-to-mesenchymal transition by activating the Wnt/ $\beta$-catenin signaling pathway. Oncotarget. 2017; 8:77241-53. https://doi.org/10.18632/oncotarget.20455.

61. Zhou B, Wang GZ, Wen ZS, Zhou YC, Huang YC, Chen Y, Zhou GB. Somatic Mutations and Splicing Variants of Focal Adhesion Kinase in Non-Small Cell Lung Cancer. J
Natl Cancer Inst. 2017 Jul 17. https://doi.org/10.1093/jnci/ djx157. [Epub ahead of print].

62. Yang Q, Feng F, Zhang F, Wang C, Lu Y, Gao X, Zhu Y, Yang Y. LINE-1 ORF-1p functions as a novel HGF/ETS-1 signaling pathway co-activator and promotes the growth of MDA-MB-231 cell. Cell Signal. 2013; 25:2652-2660. 